\title{
Chemical characterization of three large oceanic diatoms: potential impact on water column chemistry
}

\author{
Joel C. Goldman ${ }^{1}$, Dennis A. Hansell ${ }^{2}$, Mark R. Dennett ${ }^{1}$ \\ ${ }^{1}$ Woods Hole Oceanographic Institution, Woods Hole, Massachusetts 02543, USA \\ 2 Bermuda Biological Station, 17 Biological Station Lane, Ferry Reach GE 01, Bermuda
}

\begin{abstract}
Three large diatoms, Stephanopyxis palmeriana (Greville) Grunow, Pseudoquinardia recta von Stosch, and Navicula sp. (cell volumes $1.15 \times 10^{5}$ to $3.83 \times 10^{5} \mu^{3}$ ), were isolated from the Sargasso Sea and cultivated in batch cultures under low irradiance. Growth rates $\mu$ of each species occurred in 2 phases, an exponential phase where $\mu$ varied from 0.72 to $1.12 \mathrm{~d}^{-1}$ and a much slower transition phase that lasted from 3 to $6 \mathrm{~d}$. We suspect that diffusion limitation of nutrient transport controlled growth rates during this latter phase. Exponential growth rates were rapid enough to meet the requirements of a bloom scenario whereby total annual new production in a locale such as the Sargasso Sea could be met in a single $21 \mathrm{~d}$ bloom. The C:N:P ratio of all 3 species was close to the Redfield proportions during exponential growth. Uncoupling between photosynthesis and nutrient acquisition was evident in 1 species, S. palmeriana, with carbon accumulation, both in the form of phytoplankton carbon and dissolved organic carbon, continuing well into the stationary phase, long after nutrients were depleted from the growth medium. In fact, $50 \%$ of particulate organic carbon production occurred after the culture entered the stationary phase. Clearly there is ambiquity in the traditional definition of new production which implies that over a relatively short time scale a balance exists between new nitrogen entering the euphotic zone and new carbon production, assuming a Redfield stoichiometry between cellular carbon and nitrogen. The excess carbon, both particulate and dissolved, could lead to large discrepancies in estimates of new production.
\end{abstract}

\section{INTRODUCTION}

Large diatoms $\left(>10^{5} \mu \mathrm{m}^{3}\right.$ in volume) are ubiqitous in oligotrophic regions of the world's oceans. Generally, they are present in very low numbers, ranging from ca 50 cells $\mathrm{l}^{-1}$ for fairly large species such as Hemiaulis hauckii and Rhizosolenia alata (ca $10^{5}$ to $5 \times 10^{5} \mu \mathrm{m}^{3}$ ) (Guillard \& Kilham 1977) to $<1$ cell $\mathrm{m}^{-3}$ for the giant species Ethmodiscus rex $\left(>5 \times 10^{8} \mu^{3}\right)^{3}$ (Belyayeva 1972). Why these large species persist in nutrient impoverished environments and why they frequently bloom in such regions are unanswered questions that have plagued oceanographers for a long time (Guillard \& Kilham 1977, Clemons \& Miller 1984).

As one of us has concluded in recent papers (Goldman 1988, in press), the role these large phototrophs

- Contribution No. 8160 from the Woods Hole Oceanographic Institution play in oceanic primary production may be far more important than previously believed. Specifically, large diatoms, by blooming episodically, may make a disproportionately high contribution to new production that could go unnoticed with conventional sampling strategies. This conclusion is based on the simple facts that the carbon content of 1 large diatom equals that of 'many' small phototrophs and that a very small seed population of large cells residing at the base of the euphotic zone has the potential to respond rapidly to an episodic injection of new nutrients across the nutricline with a burst of new primary production. The large cells could sink quickly into deeper waters or be grazed by vertically migrating large metazoans or fish, leading to a short, efficient food chain. Only a few such events, which would be exceedingly difficult to document, could account for a sizeable fraction of the higher contemporary estimates of new production (Goldman 1988, in press). 
A key question regarding the potential role of large diatoms as important contributors to new production is whether or not growth rates of these phototrophs in relatively dim light (corresponding to levels that might be found at the base of the euphotic zone of oligotrophic waters) are fast enough to meet the requirements of different episodic scenarios such as those constructed earlier to form the basis of the large diatom -new production scheme (Goldman 1988, in press). For example, according to one scenario developed, the entire contemporary estimate for annual new production in the Sargasso Sea of Jenkins \& Goldman (1985) ( $5 \mathrm{~mol} \mathrm{O} 2 \mathrm{~m}^{-2} \mathrm{yr}^{-1}$ ) could be achieved in one $21 \mathrm{~d}$ bloom period if the phytoplankton growth rate was sustained at ca $0.6 \mathrm{~d}^{-1}$, assuming the following: a seed population of 1 diatom $\mathrm{l}^{-1}$, cell volume $5 \times 10^{5} \mathrm{um}^{3}$ [equivalent cell diameter (ecd) ca $100 \mu \mathrm{m}$ ], photosynthetic quotient (PQ) 1.4, and all new production restricted to the bottom $25 \mathrm{~m}$ of the euphotic zone (Goldman in press). To address this type of question one of us grew in batch culture 6 recent isolates of large diatoms ranging in size from $3.2 \times 10^{4}$ to $6.8 \times 10^{5} \mathrm{\mu m}^{3}$ (ecd ca 40 to $110 \mu \mathrm{m})$. Growth rates of 4 species in this group were found to be fast enough at low light $(60$ $\mu$ Einsteins $\mathrm{m}^{-2} \mathrm{~s}^{-1}$ ) to meet the requirements of several different episodic scenarios (including the one just described) that would result in levels of new production equivalent to the Jenkins \& Goldman estimate (Goldman in press). In the current study we expand on these results to characterize the cellular chemistry of the 3 fastest growing species in this group under bloom conditions simulating those found at the base of the euphotic zone of a typical oligotrophic locale. Suprisingly, there are scant data of this type available in the literature for large diatoms. The results have bearing on the important questions of what the sources of biomass exiting in surface waters are and how this new production is coupled to new nutrient input in to the euphotic zone.

\section{METHODS}

Test species and enrichment medium. Three large diatoms, Stephanopyxis palmeriana (Greville) Grunow (cell volume $3.83 \times 10^{5} \mu^{3}$, ecd $90 \mu \mathrm{m}$ ), Pseudoguinardia recta von Stosch (cell volume $1.15 \times 10^{5} \mu^{3}$, ecd $60 \mu \mathrm{m}$ ), and Navicula sp. (cell volume $1.46 \times 10^{5} \mu^{3}$, ecd $65 \mu \mathrm{m}$ ) (see Table 1) were obtained by net tows at about $100 \mathrm{~m}$ depth in the Sargasso Sea during May 1989 and June 1990. Isolates of each species were prepared by pipetting individual cells into pasteurized and weakly enriched Sargasso seawater in test tubes immediately after the net was retrieved. The tubes were held in an incubator aboard ship under low, bluefiltered light (ca $60 \mu$ Einsteins $\mathrm{m}^{-2} \mathrm{~s}^{-1}$ ) and at $20^{\circ} \mathrm{C}$ and then under similar conditions in the laboratory upon return to port. No attempt was made to make the isolates axenic. The enrichment medium (Schöne \& Schöne 1982) contained $40 \mu \mathrm{M} \mathrm{NaNO}_{3}, 2.58 \mu \mathrm{M}$ $\mathrm{NaHPO}_{4}, 35.7 \mu \mathrm{M} \mathrm{Na} \mathrm{SiO}_{3}, 2.16 \mu \mathrm{M} \mathrm{Na}{ }_{2}$ EDTA, 0.215 $\mu \mathrm{M} \mathrm{FeSO}, 0.073 \mu \mathrm{M} \mathrm{MnCl}$, and $0.5 \mu \mathrm{g} 1^{-1}$ each of vitamin $B_{12}$, biotin, and thiamine added to Sargasso seawater that was filtered through glass fiber filters (Whatman GF/F) and pasteurized at $90^{\circ} \mathrm{C}$ for $2 \mathrm{~h}$ in polycarbonate bottles. This medium was used both to maintain the cultures and for the batch growth studies.

Batch growth experiments. Three batch growth experiments were performed in $12 \mathrm{l}$ glass carboys holding 81 of medium, 1 for each species. The carboys were positioned in a rectangular flowing water bath made of plexiglass, lighted on both sides with fluorescent bulbs that were filtered with blue acetate sheeting. Irradiance levels nominally were $80 \mu$ Einsteins $\mathrm{m}^{-2} \mathrm{~s}^{-1}$ (see Table 1) and were measured directly in the carboys with a Biospherical Instruments QSL-100 $4 \pi$ sensor. Cultures were maintained at $20^{\circ} \mathrm{C}$ on a $12 \mathrm{~h}$ light-dark cycle. Inocula for each experiment were a few cells $\mathrm{ml}^{-1}$ taken from stock cultures. Samples for cell counts and some nutrient measurements were taken daily throughout the course of the experiments which generally lasted for 2 to $3 \mathrm{wk}$ until cultures had reached the late stationary phase. Sampling for cellular constituents was started several or more days after visible growth was observed. The cultures were mixed once daily just before sampling. Specific growth rates ( $\mu$ in $\mathrm{d}^{-1}$ ) were calculated by regression analysis as the slope of the linear portion of the curve of In cell number vs time

Chemical and biological measurements. Cell counts were made on $25 \mathrm{ml}$ samples preserved in Lugol's solution. The entire sample was counted with a stereo microscope in the early stages of growth and smaller subsamples were counted as cell numbers increased. One $\mathrm{ml}$ samples were counted in a Sedwick-Rafter slide and greater volumes in a $5 \mathrm{~cm}$ plastic Petri dish. A minimum of 50 and more typically 200 to 1000 cells per sample were counted. Particulate organic carbon (POC) and particulate organic nitrogen (PON) were measured with either Perkin Elmer $240 \mathrm{C}$ or 2400 Elemental Analyzers on 25 to $100 \mathrm{ml}$ samples retained on Whatman GF/F glass-fiber filters that were precombusted overnight at $550^{\circ} \mathrm{C}$. Particulate organic phosphorus (POP) was measured on $25 \mathrm{ml}$ samples retained on acid washed and pre-combusted GF/F filters. The samples were combusted and dissolved according to the procedures of Solorzano \& Sharp (1980) and then soluble reactive phosphorus was measured (Murphy \& Riley 1962). Biogenic silica was measured on $25 \mathrm{ml}$ samples retained on $1.0 \mu \mathrm{m}$ Nuclepore filters (Paasche 1980). Chlorophyll a was measured on 
$25 \mathrm{ml}$ samples retained on GF/F filters (Strickland \& Parsons 1972). Ammonium (McCarthy \& Kamykowski 1972), $\mathrm{NO}_{3}^{-}$and $\mathrm{NO}_{2}^{-}$(Wood et al. 1967), soluble reactive phosphorus, and dissolved silicon (Parsons et al. 1984) were measured on the filtrates.

Dissolved organic carbon (DOC) was measured in all 3 experiments whereas total dissolved nitrogen (TDN) was measured only in the experiments involving Stephanopyxis palmeriana and Pseudoguinardia recta. Concentrations of DOC and TDN were determined by high-temperature catalytic oxidation (Suzuki et al. 1985, Sugimura \& Suzuki 1988). Several modifications have been made, however, and these are described by Hansell (in press). In essence, a quartz combustion tube was maintained at a temperature of $720^{\circ} \mathrm{C}$ in a Thermolyne Type 21125 tube furnace. Hydrocarbon-free oxygen carrier gas delivered the important combustion products $\left(\mathrm{CO}_{2}\right.$ and $\left.\mathrm{NO}\right)$ first to a Beckman Model 880 non-dispersive infrared $\mathrm{CO}_{2}$ detector and then, in series with the infrared detector, to an Antek Model 720 chemiluminescence detector for NO counts. With the 2 detectors in series, simultaneous DOC and TDN measurements were possible with each $100 \mu$ injection. With 4 to 5 replicate injections the coefficient of variation was generally less than $5 \%$ for both DOC and TDN. Dissolved organic nitrogen (DON) concentrations were calculated as the difference between the concentration of TDN and total DIN. Procedures for calibration of the analytical system and for daily conditioning of the combustion column have been described by Hansell et al. (in press). Due to cost and availability considerations, $0.5 \% \mathrm{Pt}$ on alumina (Shimadzu Corp.) was used rather than the $3 \% \mathrm{Pt}$ on alumina catalyst (Sumika Chemical Analysis Service) used by Sugimura \& Suzuki (1988). Although they argued that the quantity of $\mathrm{Pt}$ on the catalyst support is a critical variable for efficient combustion of DOC. Hansell et al. (in press) found no significant difference between these 2 catalysts.

\section{RESULTS}

\section{Growth and nutrient uptake characteristics}

Cell division occurred in 2 phases in each experiment, an initial exponential phase (phase I) followed by a slower transitional phase (phase II) (Figs. 1A, 2A \& $3 \mathrm{~A})$. The phases are depicted in appropriate figures with vertical dashed lines. Specific growth rates $\mu$ during the initial exponential phase were $0.72 \mathrm{~d}^{-1}$ for Navicula sp., $0.87 \mathrm{~d}^{-1}$ for Pseudoguinardia recta, and $1.12 \mathrm{~d}^{-1}$ for Stephanopyxis palmeriana (Table 1). The duration of the transitional phase and $u$ during this period varied from ca $3 \mathrm{~d}$ and ca $0.2 \mathrm{~d}^{-1}$ for $S$. palmeriana to ca $6 \mathrm{~d}$ and $0.1 \mathrm{~d}^{-1}$ for the other 2 species.
The experiment involving $P$. recta was ended before the stationary phase (phase III) was reached (Fig. 2A). Cell numbers about doubled through the transition phases for each species. Growth of Navicula sp. was marked by a long lag period of $5 \mathrm{~d}$ (Fig. 3A).

The patterns of nutrient utilization varied between experiments. Dissolved nutrients $\left(\mathrm{NO}_{3}{ }^{-}, \mathrm{PO}_{4}{ }^{-3}\right.$, and silicon) were in excess at the end of the exponential phase in all 3 cultures (Figs. 1B, C, D, 2B, C, D, 3B, C, $D)$. In fact, they never were exhausted in the culture of
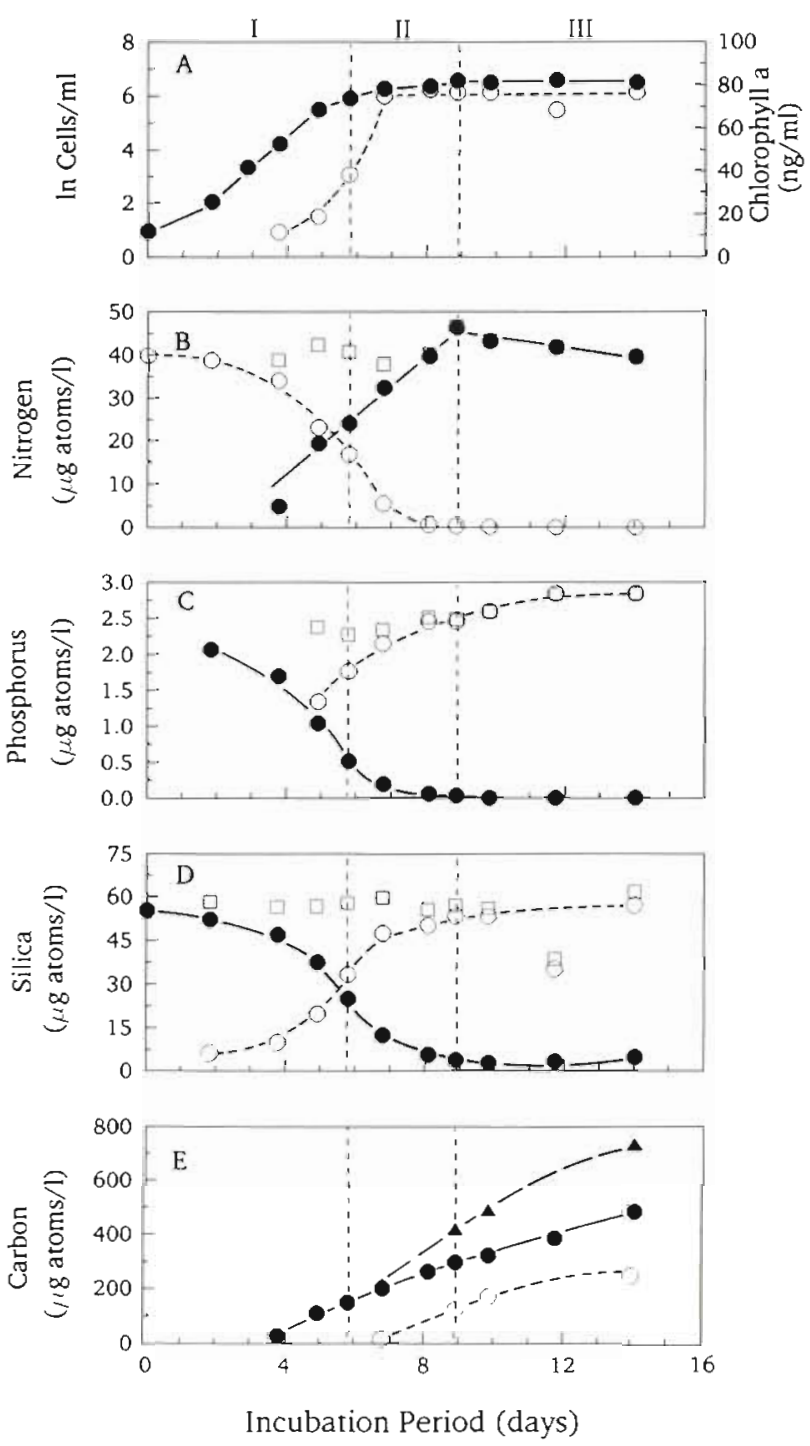

Fig. 1. Stephanopyxis palmeriana. Time course of growth and nutrient transformations during batch cultivation. (A) Changes in cell numbers ( $)$ and chlorophyll $a(O)$; (B) changes in PON $+\mathrm{NO}_{3}^{-}(\square), \mathrm{NO}_{3}^{-}(0)$, and PON (•); (C) changes in $\mathrm{POP}+\mathrm{PO}_{4}^{-3}(\square) \mathrm{PO}_{4}^{-3}(\bullet)$, and POP (C); (D) changes in

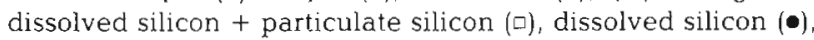
and particulate silicon (O); (E) changes in TOC (4), POC (•), and DOC (o). Curves in all figures were drawn by visual inspection to show trends only 

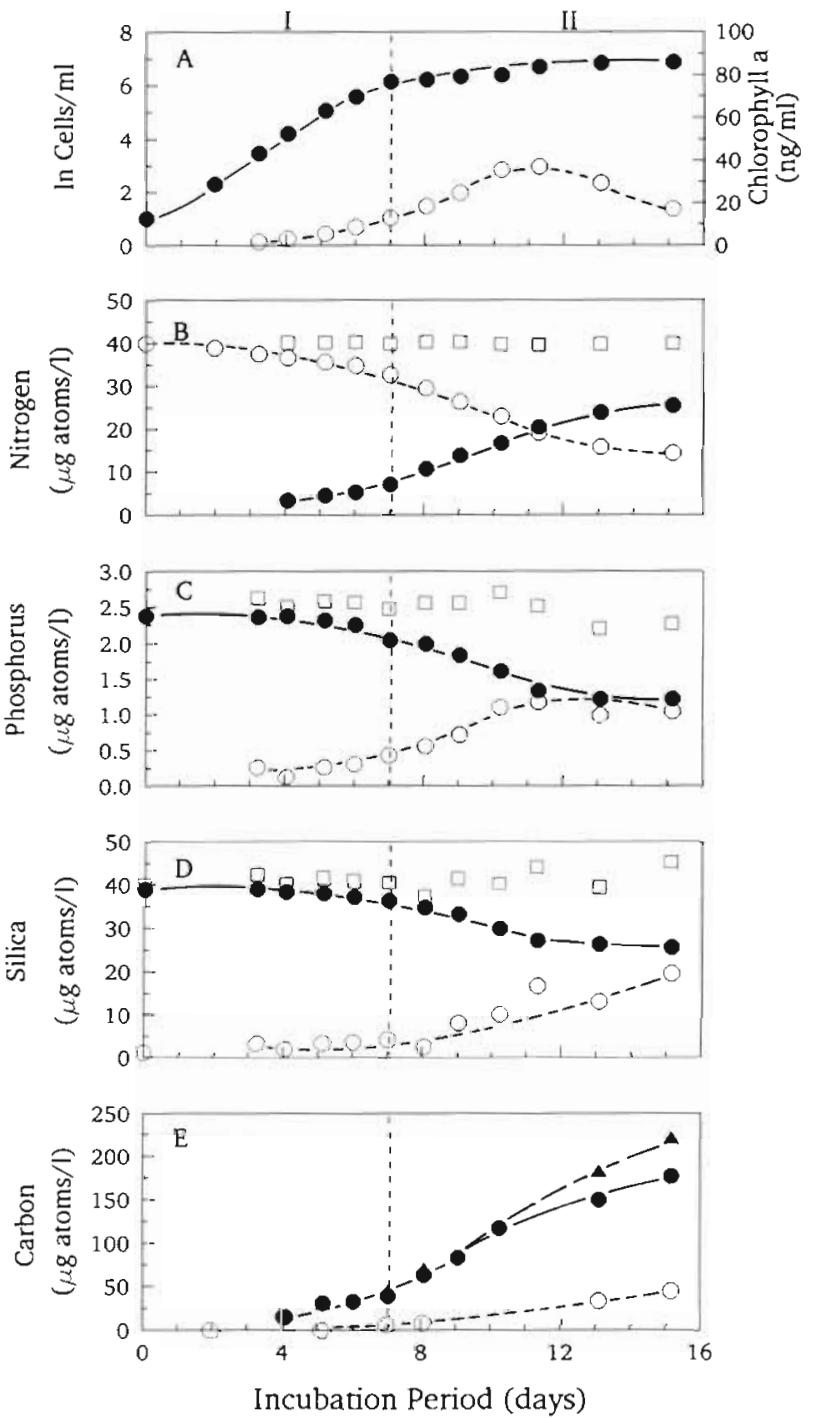

Fig. 2. Pseudoquinardia recta. Same as Fig. 1

Pseudoguinardia recta (Fig. $2 \mathrm{~B}, \mathrm{C}, \mathrm{D}$ ) and only $\mathrm{NO}_{3}{ }^{-}$ was undetectable by the end of the transition phase in the culture of Navicula sp (Figs. 3B, C, D). In the culture of Stephanopyxis palmeriana, however, depletion of $\mathrm{NO}_{3}{ }^{-}$and $\mathrm{PO}_{4}{ }^{-3}$ occurred by the end of the short transition phase (Fig. 1B, C) although silicon remained in excess throughout the experiment, falling to about $3 \mu \mathrm{g}$-at. $\mathrm{l}^{-1}$ by the early stationary phase before rising slightly to ca $5 \mu \mathrm{g}$-at. $\mathrm{l}^{-1}$ at the end of the experiment (Fig. 1D). Decreases in $\mathrm{NO}_{3}^{-}, \mathrm{PO}_{4}^{-3}$, and silicon were matched by increases in the respective particulate components so that a mass balance for each nutrient was maintained throughout the course of the experiments. PON values were not obtained in the experiment involving Navicula sp. due to problems with the
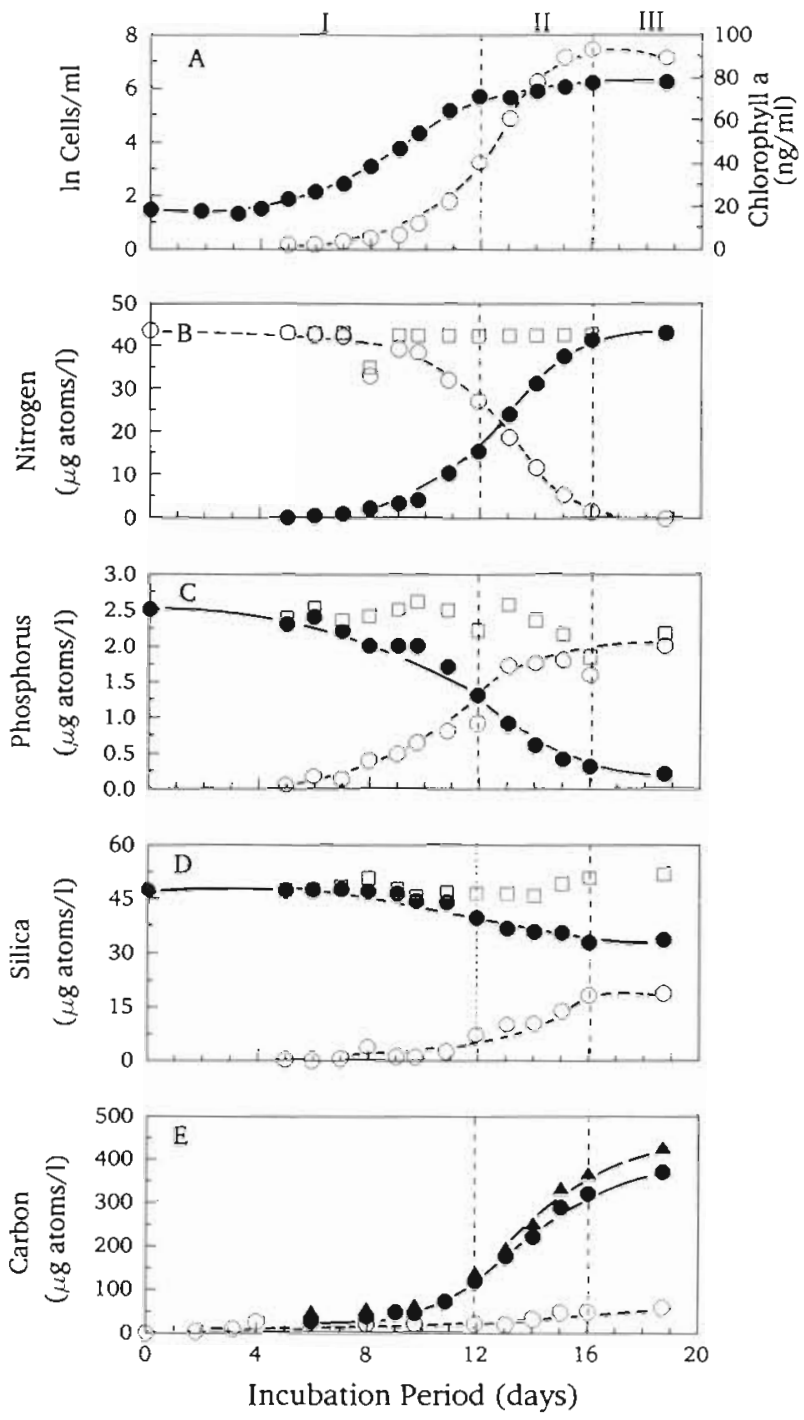

Fig. 3. Navicula sp. Same as Fig. 1

Perkin Elmer 2400 analyzer. Instead, PON was estimated in this experiment by changes in $\mathrm{NO}_{3}{ }^{-}$concentration between sampling intervals (Fig. 3B). Ammonium concentrations remained below the detection limit throughout all 3 experiments. Similarly, $\mathrm{NO}_{2}{ }^{-}$ was undetectable in the experiments involving $S$. palmeriana and $P$. recta, but did increase slightly throughout the exponential phase in the culture of Navicula sp. to ca $0.6 \mu \mathrm{g}$-at. $\mathrm{l}^{-1}$ before falling to ca $0.1 \mu \mathrm{g}$-at. $\mathrm{l}^{-1}$ by the end of the experiment. Increases in chlorophyll a matched those for the other particulate constituents, except that chlorophyll degradation was evident during the latter stages of the transition phase in the culture of $P$. recta (Fig. 2A) and during the stationary phase in the culture of Navicula sp. (Fig. 3A) 
Table 1. Summary of irradiance levels used, cell sizes, growth rates, and cell quotas for various cell constituents of large diatoms grown in batch culture

\begin{tabular}{|lccc|}
\hline Parameter & Stephanopyxis palmeriana & Pseudoguinardia recta & Navicula sp. \\
\hline Irradiance level $\left(\mu\right.$ Einsteins $\left.\mathrm{m}^{-2} \mathrm{~s}^{-1}\right)$ & 76 & 84 & 80 \\
Cell volume $\left(10^{5} \mu \mathrm{m}^{3}\right)$ & 3.833 & 1.152 & 1.460 \\
Equivalent cell diameter $(\mu \mathrm{m})$ & 90 & 60 & 65 \\
Specific growth rate $\mu\left(\mathrm{d}^{-1}\right)$ & 1.12 & 0.87 & 0.72 \\
$\quad$ Exponential & 0.19 & 0.11 & 0.08 \\
$\quad$ Transition & & & \\
a Based on a spherical shape & & & \\
\hline
\end{tabular}

\section{Photosynthetic carbon production and DOC excretion}

A common feature of the experiments involving Stephanopyxis palmeriana and Navicula sp. was for POC to increase continuously even after the cultures had reached the stationary phase (Figs. $1 \mathrm{E} \& 3 \mathrm{E}$ ). In effect, photosynthetic carbon incorporation became uncoupled from cell division and nutrient assimilation well into the stationary phase in both of these cultures. There was no evidence of this uncoupling in the culture of Pseudoguinardia recta, at least for nitrogen and silicon (Figs. 2B, D), as the stationary phase was never reached and these 2 nutrients were assimilated along with carbon throughout the experiment. However, POP production ceased midway into the transition phase in this culture (Fig. 2C).

Concomitant with the switch to the transition phase in all 3 cultures was the accelerated production of DOC which continued until the experiments were ended (Figs. $1 E, 2 E \& 3 E)$. Concentrations of DOC shown in these figures are the difference between total DOC values and initial values, which represent the background DOC in the Sargasso seawater and in the EDTA and vitamins added to the medium. Production of DOC was most pronounced in the culture of Stephanopyxis palmeriana: $40 \%$ of the total organic carbon (TOC) produced after the exponential phase $(\mathrm{TOC}=\mathrm{POC}+\mathrm{DOC})$ and $34 \%$ for the entire experiment was as DOC as opposed to 22 and $20 \%$ respectively in the culture of $P$. recta and 13 and $13 \%$ respectively in the culture of Navicula sp. (Table 2 ). Virtually all of the DOC produced in the culture of Navicula sp. before the transition phase actually occurred during the lag phase (Table 2, Fig. 3E).

There was no evidence of DON production throughout the two experiments in which DON was measured. A mass balance for the sum of $\mathrm{PON}+\mathrm{NO}_{3}^{-}$was maintained in both experiments and total DON showed no consistent pattern of increase through the experiments (Fig. 4). The DON that was measured originated from the Sargasso seawater and the EDTA and vitamins added to the medium.

\section{Cellular nutrient quotas and ratios}

Cell quotas for chlorophyll, nitrogen, phosphorus, and silicon were relatively invariant throughout the experiment involving Stephanopyxis palmeriana (Figs. 5A, C, D, E); there was, however, a pronounced increase in the carbon cell quota from ca $5 \mathrm{ng} \mathrm{C}$ cell ${ }^{-1}$ during exponential growth to ca $9 \mathrm{ng} \mathrm{C} \mathrm{Cell}^{-1}$ by the end of this experiment (Fig. 5B), resulting in large increases in both the cellular $C: N$ and $C: P$ ratios during this period (Fig. 6A, B), but not the cellular $\mathrm{N}: \mathrm{P}$ and $\mathrm{Si}$ : $\mathrm{N}$ ratios (Figs $6 \mathrm{C}, \mathrm{D}$ ).

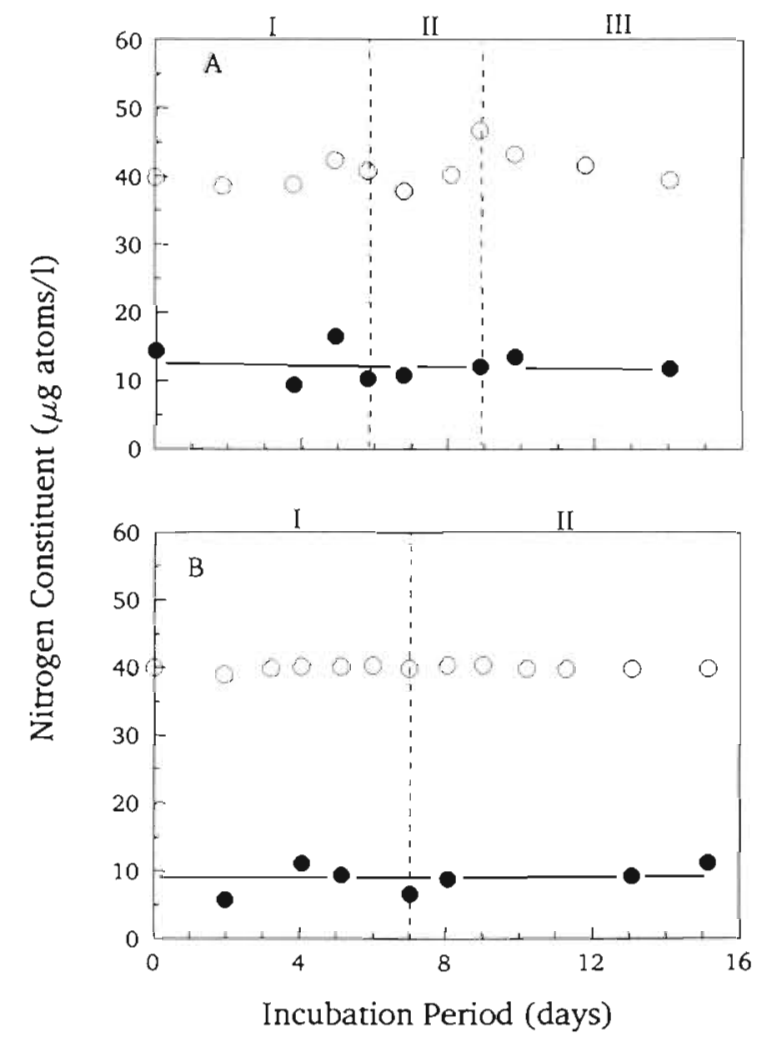

Fig. 4. Changes in DON ( $\bullet$ during time course experiments with (A) Stephanopyxis palmeriana and (B) Pseudoquinardia recta. Data for $\mathrm{PON}+\mathrm{NO}_{3}{ }^{-}$(c) repeated in both panels from Figs. $1 \mathrm{~B} \& 2 \mathrm{~B}$ for comparison 
Table 2. Percent contribution of particulate organic carbon (POC) and dissolved organic carbon (DOC) to total organic carbon production during different growth phases of large diatoms in batch cultures

\begin{tabular}{|c|c|c|c|c|c|c|}
\hline \multirow[t]{2}{*}{ Growth phase } & \multicolumn{2}{|c|}{ Stephanopyxis palmeriana } & \multicolumn{2}{|c|}{ Pseudoguinardia recta } & \multicolumn{2}{|c|}{ Navicula sp. } \\
\hline & POC & DOC & POC & DOC & $\mathrm{POC}$ & DOC \\
\hline Exponential & 100 & 0 & 87 & 13 & 84 & $16^{d}$ \\
\hline Transition-stationary & 60 & 40 & 78 & 22 & 87 & 13 \\
\hline Total & 66 & 34 & 80 & 20 & 87 & 13 \\
\hline
\end{tabular}
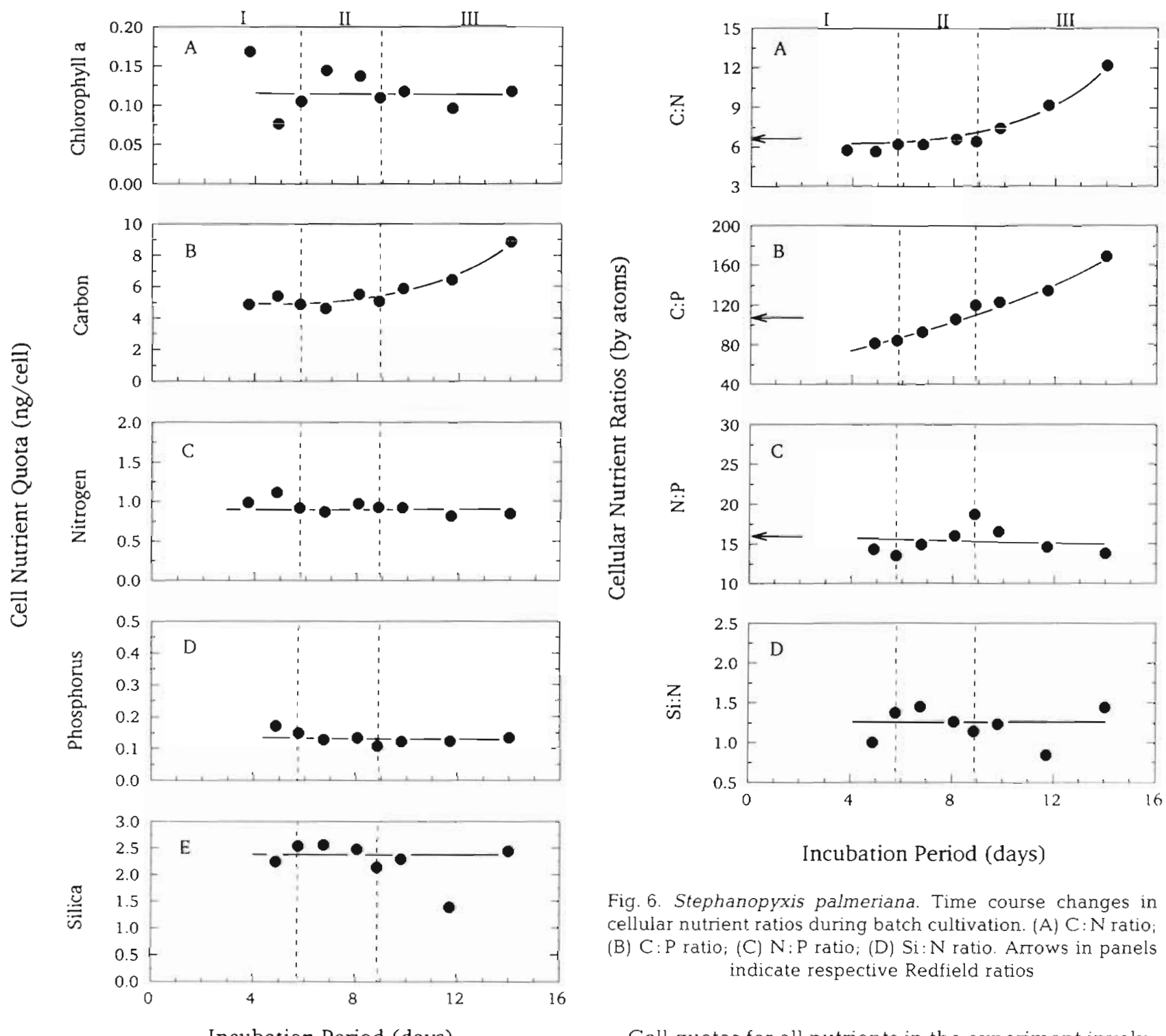

Incubation Period (days)

Fig. 6. Stephanopyxis palmeriana. Time course changes in cellular nutrient ratios during batch cultivation. (A) C:N ratio; (B) C:Pratio; (C) N:P ratio; (D) Si: N ratio. Arrows in panels indicate respective Redfield ratios

Cell quotas for all nutrients in the experiment involving Pseudoguinardia recta displayed a similar pattern of decreasing through the exponential phase, increasing in the early stages of the transition phase before leveling off (Fig. 7) and, in the the case of phosphorus,

Fig. 5. Stephanopyxis palmeriana. Time course changes in cell quotas for different nutrients during batch cultivation. (A) Chlorophyll $a_{i}$ (B) carbon; (C) nitrogen; (D) phosphorus; 

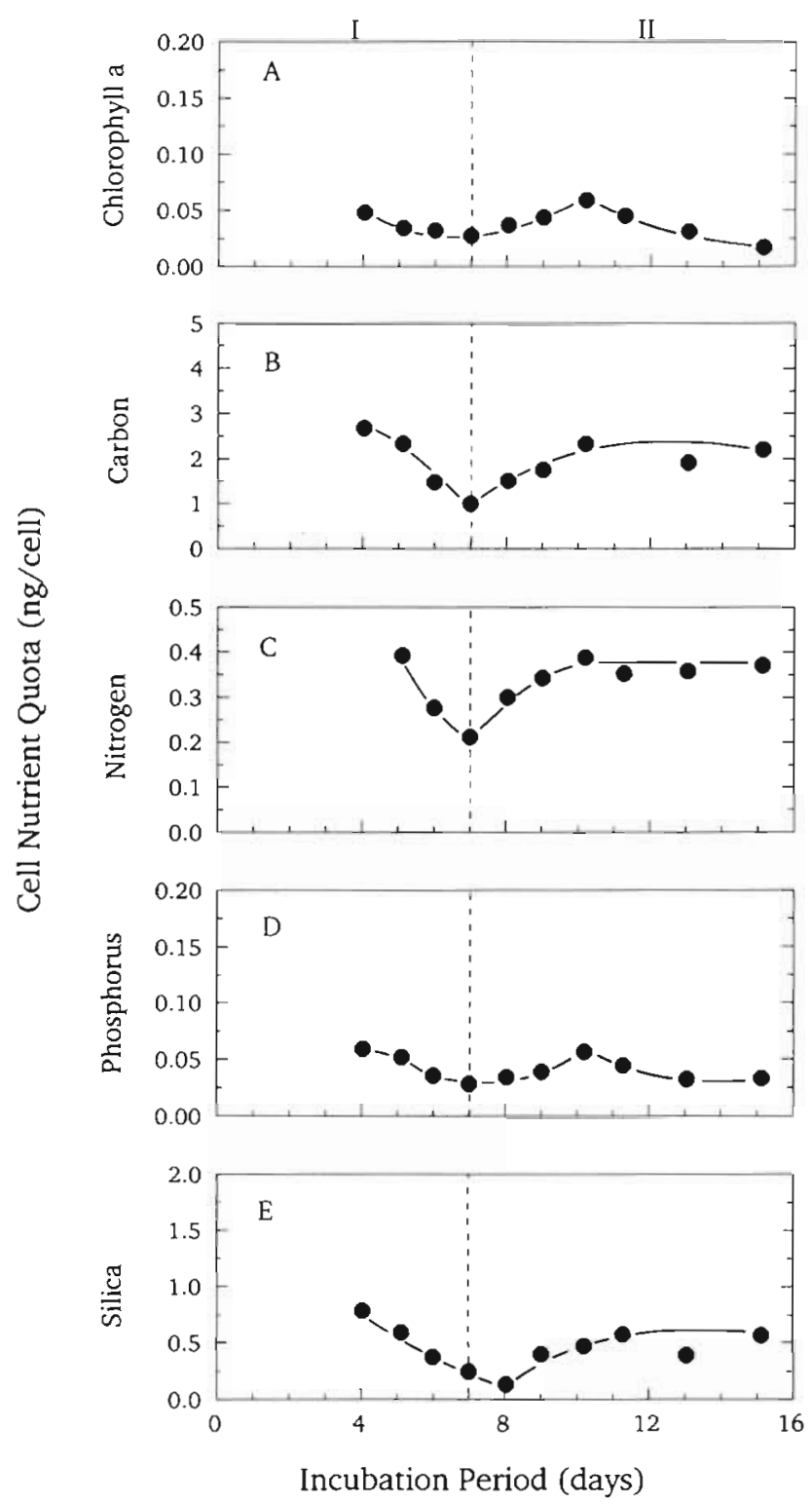

Fig. 7. Pseudoquinardia recta. Same as Fig. 5

actually decreasing by the end of the experiment (Fig. 7D). These cell quota changes translated to relatively invariant cellular $\mathrm{C}: \mathrm{N}$ (Fig. 8A) and $\mathrm{Si}: \mathrm{N}$ ratios (Fig. $8 \mathrm{D})$ in this experiment, but to large increases during the transition phase in the cellular C:P (Fig. 8B) and $\mathrm{N}$ : $\mathrm{P}$ ratios (Fig. $8 \mathrm{C}$ ). The patterns of change in both the cellular nutrient quotas (Fig. 9) and cellular nutrient ratios (Fig. 10) during the experiment dealing with Navicula sp. generally seemed to follow those in the $P$. recta experiment although the data were too limited during the exponential portion of this experiment to allow firm comparison to be made between the 2 experiments. There also was a small increase in the cellular $C: N$ ratio from ca $7: 1$ during exponential
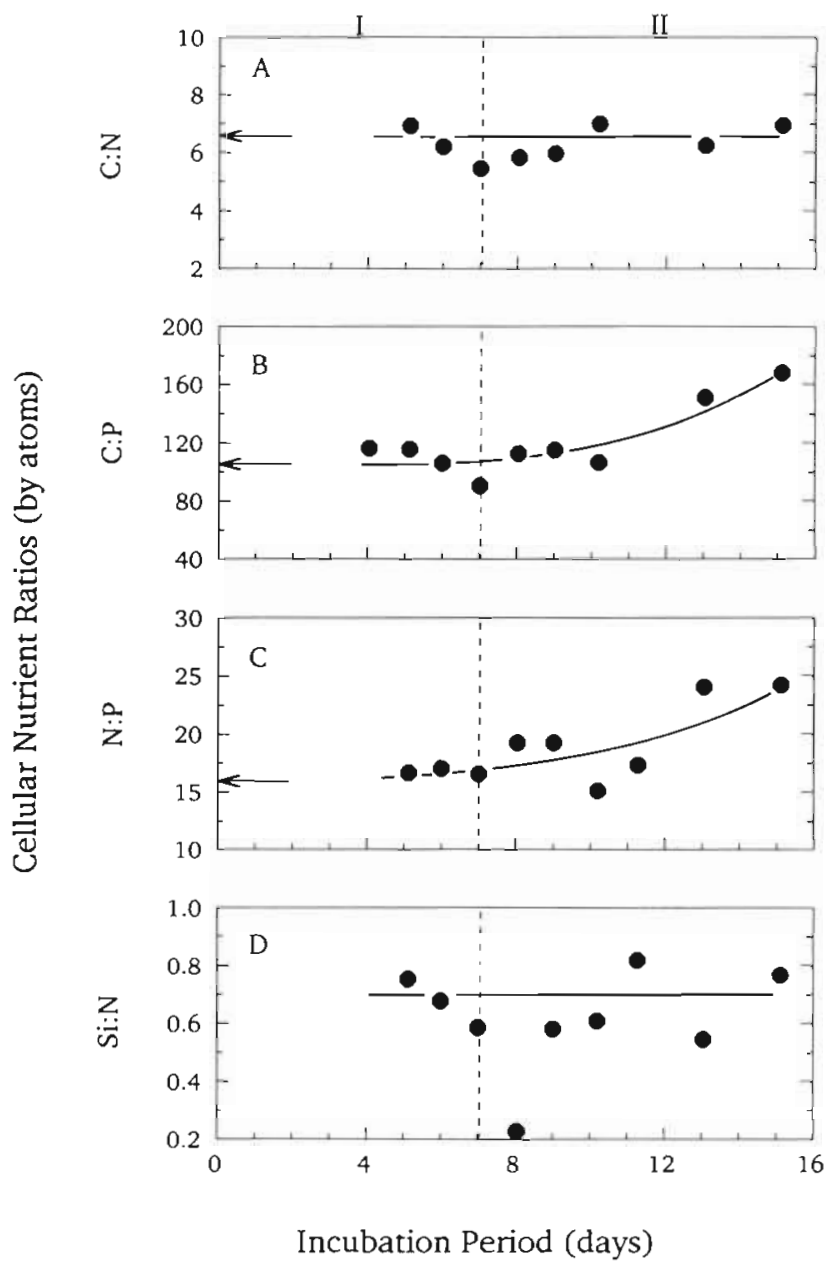

Fig. 8. Pseudoquinardia recta. Same as Fig. 6

growth to ca $9: 1$ by the end of the experiment involving Navicula sp. (Fig. 10A), unlike the invariant $\mathrm{C}: \mathrm{N}$ ratio displayed in the experiment involving $P$. recta (Fig. 8A).

The cellular nutrient quotas and ratios of the 3 species were compared at the end of exponential growth (Table 3) by drawing lines through the data by visual inspection. The 2 data sets for cell quotas and ratios compiled in Table 3 are not internally consistent for this reason. For example, nutrient ratios presented in this table are slightly different than those based on cell quota values.

The magnitude of the cell quotas generally reflected the size of each species. On a per unit volume basis, it was clear that Navicula sp., although intermediate in size between the other 2 species, had the highest amounts of chlorophyll, carbon, nitrogen and phosphorus and almost the same amount of silicon as Stephanopyxis palmeriana, which was over 2.5 times larger by volume (Table 3 ). The nutrient ratios were very close to the Redfield C:N : P ratio of $106: 16: 1$ for 

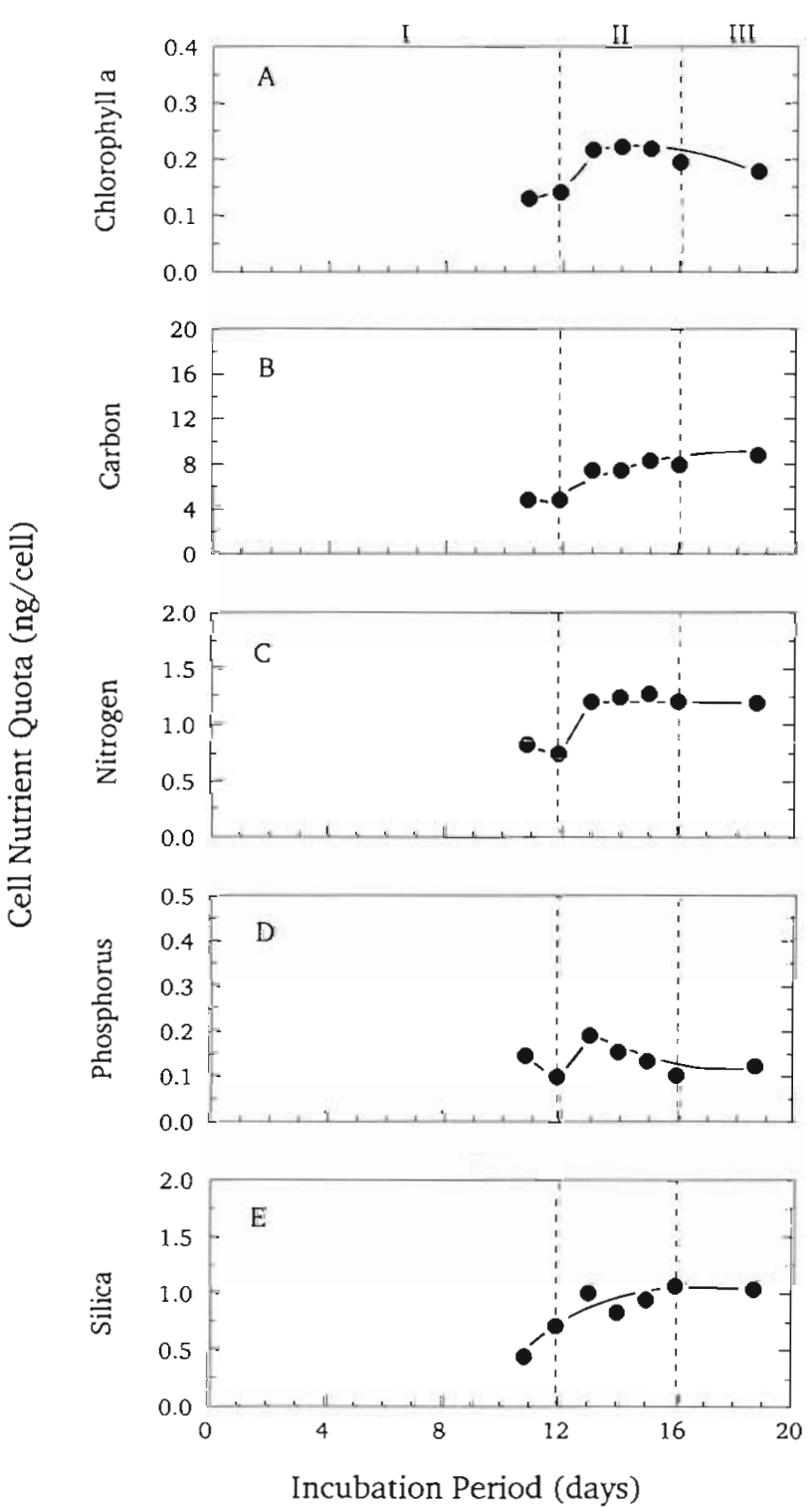

Fig. 9. Navicula sp. Same as Fig. 5

all 3 species. The Si: $\mathrm{N}$ ratio by atoms was highest for S. palmeriana $(1.3 \cdot 1)$ and lowest for Navicula sp. $(0.4: 1)$ (Table 3).

\section{DISCUSSION}

\section{Growth potential of large diatoms}

Physiological studies on large phytoplankton cells represent a largely neglected research area. To date, growth rate estimates of large $\left(>10^{5} \mu \mathrm{m}^{3}\right)$ diatoms cultured in the laboratory are restricted to the few studies summarized in Table 4 . These data, which are for conditions of light saturation, were normalized to a
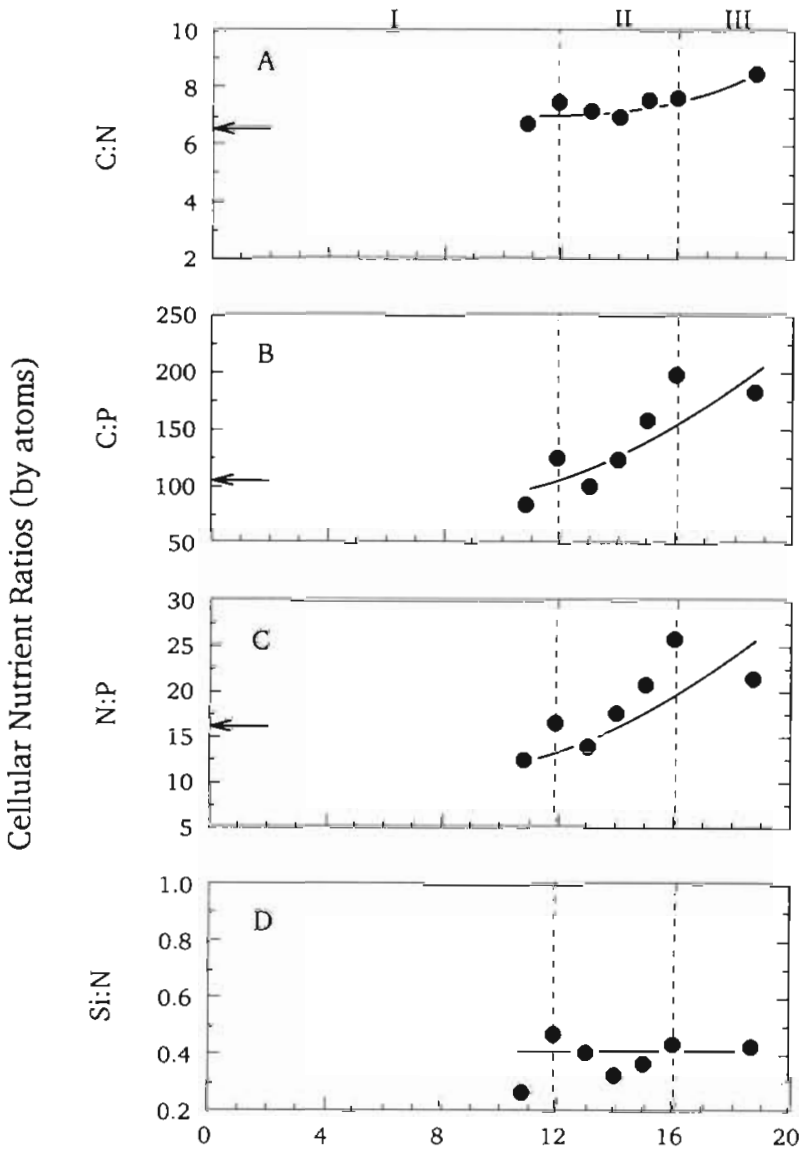

Incubation Period (days)

Fig 10. Navicula sp. Same as Fig. 6

common temperature of $20^{\circ} \mathrm{C}$ for comparison with the data from the present study. Even though this data set is limited, 2 important points emerge regarding the potential contribution of large phytoplankton species to new production. First, it does not appear that growth rates of large diatoms are tightly coupled to cell size. Although cell volumes in the data set (including our own data) span 3 orders of magnitude, no apparent allometric relationship between cell size and growth rate is evident (Fig. 11). Banse (1982) first pointed out the weakness of such relationships for diatom cell volumes between $10^{2}$ and $10^{6} \mu^{3}$ and Schöne (1982) corroborated the weakness for bigger diatoms, the data of which are included in Fig. 11.

Although the bulk of the data from Tables 1 and 4 fall near to or below the weak allometric relationship developed by Banse (1982) (which we extrapolated to larger volumes in Fig. 11), growth rates of at least 1 species, Stephanopyxis palmeriana (1.12 to $\left.1.37 \mathrm{~d}^{-1}\right)$ fall considerably above this curve. We suspect that the slightly higher value of $\mu$ for this species reported by 
Table 3. Approximate values of cell nutrient quotas and nutrient chemical ratios at the end of exponential growth of large diatoms grown in batch culture

\begin{tabular}{|c|c|c|c|}
\hline Nutrient constituent & Stephanopyxis palmeriana & Pseudoguinardia recta & Navicula sp \\
\hline \multicolumn{4}{|c|}{ Cell quota [ng cell $\left.{ }^{-1}\left(\mathrm{fg} \mu \mathrm{m}^{-3}\right)\right]$} \\
\hline Chlorophyll a & $0.11 \quad(0.3)$ & $0.03(0.3)$ & $0.15(1.0)$ \\
\hline Carbon & $5.0(13.1)$ & $1.0 \quad(8.7)$ & $4.0(27.4)$ \\
\hline Nitrogen & $0.8 \quad(2.1)$ & $0.2 \quad(1.7)$ & $0.7 \quad(4.8)$ \\
\hline Phosphorus & $0.14(0.4)$ & $0.03(0.3)$ & $0.1 \quad(0.7)$ \\
\hline Silicon & $2.5 \quad\{6.5\}$ & $0.25(2.2)$ & $0.7 \quad(4.8)$ \\
\hline \multicolumn{4}{|l|}{ Nutrient ratio, by atoms } \\
\hline$C: N$ & $6.0: 1$ & $6.5: 1$ & $7.0: 1$ \\
\hline$C: P$ & $95: 1$ & $105: 1$ & $105: 1$ \\
\hline$N: P$ & $15: 1$ & $16: 1$ & $16: 1$ \\
\hline $\mathrm{Si}: \mathrm{N}$ & $1.3: 1$ & $0.7: 1$ & $0.4: 1$ \\
\hline$C: N: P$ & $95: 15: 1$ & $105: 16: 1$ & $105 \cdot 15: 1$ \\
\hline
\end{tabular}

Table 4. Summary of sizes and growth data for large marine diatoms obtained from the literature. All cultures were maintained under saturating irradiance and growth rates were adjusted to $20^{\circ} \mathrm{C}$ using a $Q_{10}$ of 1.88 from Eppley (1972)

\begin{tabular}{|c|c|c|c|}
\hline Species & $\begin{array}{l}\text { Cell volume } \\
\left(10^{5} \mathrm{um}^{3}\right)\end{array}$ & $\begin{array}{l}\text { Specific growth rate, } u \\
\qquad\left(\mathrm{~d}^{-1}\right)\end{array}$ & Source \\
\hline $\begin{array}{l}\text { Coscinodiscus wailesii } \\
\text { Coscinodiscus asteromphilus }\end{array}$ & $\begin{array}{l}140 \\
3.27\end{array}$ & $\begin{array}{l}0.48 \\
0.36\end{array}$ & Eppley \& Sloan (1966) \\
\hline $\begin{array}{l}\text { Ditylum brightwellii } \\
\text { Coscinodiscus sp. (C } 38 \mathrm{~B}) \\
\text { Coscinodiscus sp. (CoA) }\end{array}$ & $\begin{array}{l}1.18 \\
2.75 \\
62\end{array}$ & $\begin{array}{l}1.01 \\
0.62 \\
0.55\end{array}$ & Blasco et al. (1982) \\
\hline $\begin{array}{l}\text { Coscinodiscus radiatus } \\
\text { Rhizosolenia robusta } \\
\text { Rhizosolenia alata } \\
\text { Stephanopyxis palmeriana }\end{array}$ & $\begin{array}{l}2.20 \\
1.70 \\
3.54 \\
3.50\end{array}$ & $\begin{array}{l}0.65 \\
0.78 \\
0.69 \\
1.37\end{array}$ & Schöne (1982) \\
\hline
\end{tabular}

Schöne (1982) (Table 4) relative to our value resulted because we did not attain light saturation in the current study. Sommer (1989) similarly found that growth rates of some Antarctic phytoplankton species were greater than predicted by the Banse equation. In particular, the large diatom Corethron criophilum (volume $1.92 \times 10^{6}$ $\mu \mathrm{m}^{3}$, ecd $72 \mu \mathrm{m}$ ) was found to grow at $0.40 \mathrm{~d}^{-1}$ at $0^{\circ} \mathrm{C}$, which, when extrapolated to $20^{\circ} \mathrm{C}$ with a $Q_{10}$ of 1.88 (Eppley 1972), would be comparable to the growth potential displayed by $S$. palmeriana both in the present study and that of Schöne (1982). Results of this type defy the commonly accepted notion that small cells should, on physiological principles alone, grow faster than large ones.

It is impossible to generalize from the limited data on rapid growth rates of large oceanic diatoms. We can not discount the possibility, however, that Stephanopyxis palmeriana is representative of many large diatoms capable of attaining rapid growth rates considerably above those expected from allometric relationships. The reasons why some large oceanic diatoms possess such high growth potential are obscure, but may represent an evolutionary adaptation to variable nutrient distributions that seem to exist in pelagic surface waters, both spatially and temporally; in effect, this capability can be viewed as a way for large diatoms to cope with a feast or famine existence, a survival mechanism common to many oceanic microbes (Fenchel 1982).

The second point regarding the potential for large diatoms to contribute significantly to new production is that virtually all of the growth rate data in Fig. 11 fall above the curve constructed by Goldman (in press) to represent the episodic scenario in which new production equivalent to the contemporary estimate of $5 \mathrm{~mol}$ $\mathrm{O}_{2} \mathrm{~m}^{-2} \mathrm{yr}^{-1}$ occurs during a single $21 \mathrm{~d}$ bloom for cells of varying size, assuming an inoculum of 1 cell $1^{-1}$, a PQ of 1.4, and all production occurring in the bottom $25 \mathrm{~m}$ of the euphotic zone. Thus it is plainly seen that large diatoms have the potential to make a sizeable contribution to annual new production during episodic growth periods and that this production could easily go unnoticed with conventional sampling strategies. 


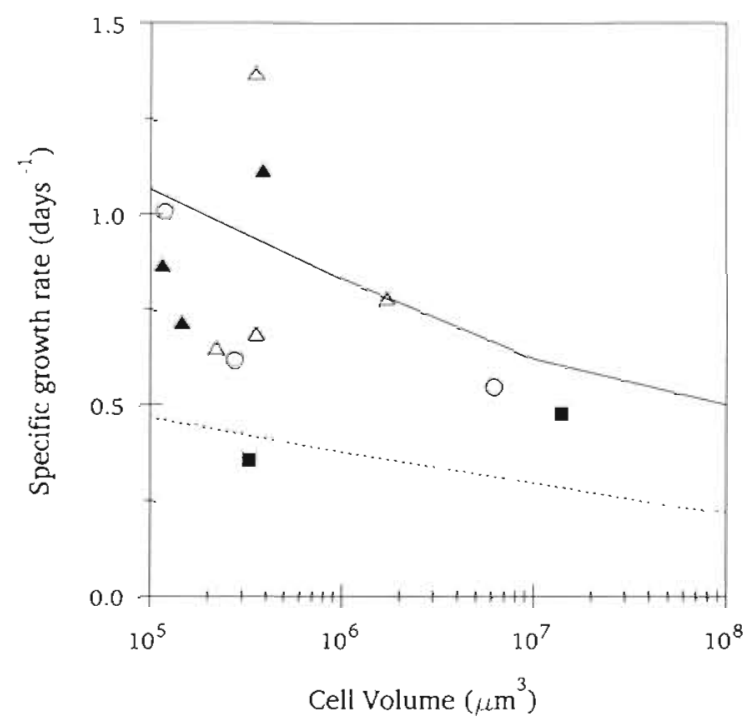

Fig. 11. Specific growth rates of large diatoms as a function of cell volume for data obtained from the literature and from the present study. Data from Eppley \& Sloan (1966) ( $\mathbf{m}$ ). Blasco et al. (1982) (c), Schöne (1982) ( $)$, and the present study (4). Allometric curve from Banse (1982) (-) and $21 \mathrm{~d}$ bloom curve from Goldman (in press) (-.--) are included in plot

We can only speculate as to why growth rates of all 3 species slowed down considerably during the prolonged transition phases that lasted for 3 to $6 \mathrm{~d}$. Even though major nutrients $\left(\mathrm{NO}_{3}{ }^{-}, \mathrm{PO}_{4}{ }^{-3}\right.$, silicon) were not exhausted at the start of the transition phases in all three experiments, particularly in those experiments involving Pseudoquindaria recta (Fig. 2) and Navicula sp. (Fig. 3) in which nutrients were in large abundance when exponential growth ended and the transition phases were longest, we can not discount the possibility of a switch from nutrient-saturated to nutrientlimited growth during this phase. This switch in nutrient status may have been caused by diffusion limitation of nutrient flux to the cell surface of these large diatoms, particularly since the cultures were only mixed once daily. Since this flux is controlled by the concentration gradient of a particular nutrient in the bulk fluid and at the cell surface and by cell size (Pasciak \& Gavis 1975), it is apparent that the ambient nutrient concentration could have decreased to a critical level during exponential growth leading to diffusion limitation and a concomitant decrease in growth rate. The impact of diffusion limitation would be most pronounced for large cells having relatively high half saturation coefficients $K_{\mathrm{s}}$ for nutrient uptake or growth (Gavis 1976). We know virtually nothing about the kinetics of nutrient uptake by large marine phytoplankton, although there is evidence that some large cold water diatoms do have unusually high $K_{\mathrm{s}}$ values for silicon (Sommer 1986).

Given the recent interest on the role iron may play in controlling new production in some oceanic locales (Martin \& Fitzwater 1988, Morel et al. 1991), it is tempting to suggest that iron limitation was the cause of the reduced growth rates in the present study. This suggestion seems unlikely, however, because the concentration of chelated iron $(0.215 \mu \mathrm{M})$ was in great excess relative to the maximum biomass produced as POC (ca $480 \mu \mathrm{M}$ in the experiment involving Stephanopyxis palmeriana), assuming that the ratio of iron to $\mathrm{POC}$ in marine diatoms typically is ca 1 to $10 \mu \mathrm{mol} / \mathrm{mol}^{-1}$ (Morel et al. 1991).

\section{Physiological characteristics of large diatoms}

Sournia (1982) pointed out vividly the tremendous range in size between phytoplankton species indigenous to different oceanic locales and the disproportionate contribution of large species to total phytoplankton biomass. Unfortunately, however, the tremendous recent interest in the microbial loop and in small phototrophs $(<5$ um) has masked the importance of the larger species to new production. In fact, it is evident from our own data that a single diatom such as Stephanopyxis palmeriana has a carbon content (ca 5 $\mathrm{ng} \mathrm{C} \mathrm{cell}^{-1}$ ) that is equivalent to ca $10^{4}$ to $10^{5}$ cyanobacterium cells with a carbon content of ca $0.2 \mathrm{pg} \mathrm{C}$ cell $^{-1}$ (Waterbury et al. 1986). Thus it is important to recognize how difficult it is to represent adequately all the important phototrophs that may contribute to primary productivity when performing standard ${ }^{14} \mathrm{C}$ assays on small volume samples; other techniques must be employed to gauge the contribution of the larger, rarer species to new production (Goldman 1988, in press).

Attainment of the Redfield ratios during exponential growth with excess nutrients present in the cultures is characteristic of phytoplankton growing at maximal rates (Goldman et al. 1979), and reinforces the general concept that the Redfield ratio is a good indicator of the nutrient status of phytoplankton populations. Equally important is the fact that in the present study the Redfield ratio was attained under light-limiting conditions. From other studies (Goldman unpubl.), we know that the light intensity used in this study $(80 \mu$ Einsteins $\mathrm{m}^{-2} \mathrm{~s}^{-1}$ ) was sub-saturating for all 3 species. The results, particularly for Stephanopyxis palmeriana, are similar to what one of us attained earlier in showing that the relationship between the $C: N$ : P ratio and the nutrient status of phytoplankton populations is independent of light intensity (Goldman 1986). Light intensity only sets the maximum possible growth rate; it is the relative growth rate at any light intensity that 


\section{A}

\section{CONVENTIONAL}

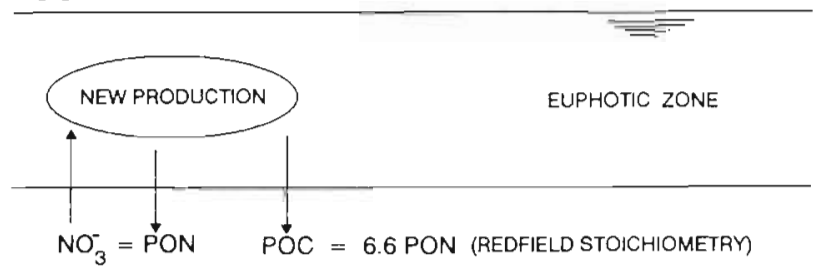

B

\section{"EXCESS " CARBON}

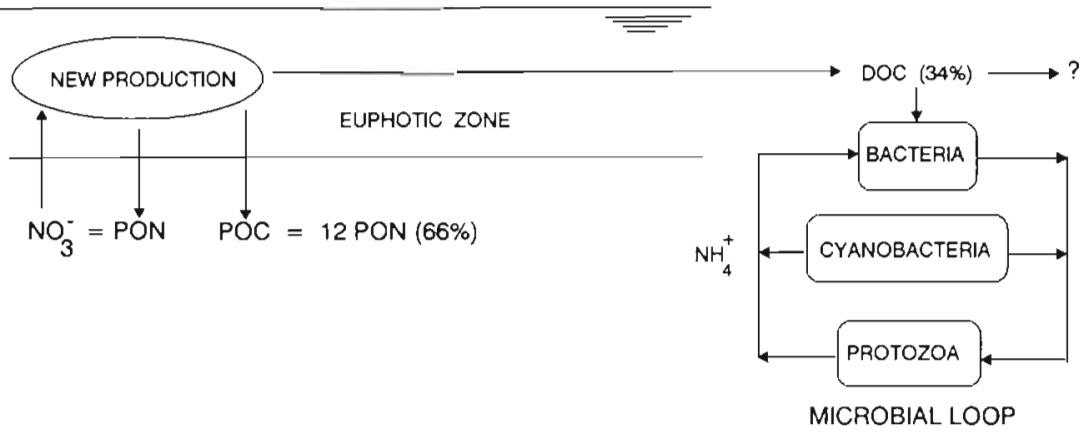

Fig. 12. Schematic diagram of (A) conventional description of new production and $(B)$ excess carbon description resulting from uncoupling between photosynthesis and nutrient acquisition this species. Brzezinski (1985) also found that the Si : N ratio of $S$. palmeriana (Greville) Grunow (1.5:1 by atoms under a light-dark cycle), was at the high end for the group of diatoms he studied, as the bulk of his data fell between $0.5: 1$ and $1.5: 1$ with a mean of $1.1: 1$.

\section{Uncoupling between photosynthesis and nutrient acquisition}

New production, as defined by Dugdale \& Goering (1967) and later by Eppley \& Peterson (1979), is that fraction of total primary production that is fueled by allochthonous nutrient inputs into the euphotic zone. In effect, a balance is maintained whereby the input of major nutrients such as dissolved nitrogen and phosphorus into the euphotic zone is equal to the flux of biogenic counterparts into deeper waters. The flux of carbon as new production is, by convention, considered to be equal to new PON production times the Redfield C: $N$ ratio of 6.6 (by atoms) (Fig. 12A). If we consider our results with Stephanopyxis palmeriana as being representive of oceanic diatoms that are able to sustain photosynthetic rates long after nutrient depletion occurs in the water column, then our view of what constitutes new production must be revised. In principle, the continuation of photosynthesis after nutrient depletion by some marine phytoplankton represents a switch from protein to carbohydrate synthesis in order to maintain cellular energy reserves. Many phytoplankton species, and diatoms in particular, are cap- 
able of prodigious carbohydrate production after nutrient depletion occurs and cell division stops (Myklestad 1974) so our results with $S$. palmeriana are not novel. However, the results provide a striking example of how new carbon production can be uncoupled from new nutrient input. In fact, in the current experiment with S. palmeriana, $50 \%$ of POC production occurred after nutrients were depleted, leading to an increase in the particulate $\mathrm{C}: \mathrm{N}$ ratio to $\mathrm{ca} 12: 1$ by atoms. Thus in this case new POC production would be about double that based on using the traditional Redfield stoichiometry between cellular carbon and nitrogen (Fig, 12B).

The situation is compounded even further when considering that DOC excretion by phytoplankton, which is photosynthate lost from the cells, is a component of new production (Legendre \& Gosselin 1989). Using our own values for Stephanopyxis palmeriana as an example, if we include $D O C$ production, then the $C: N$ ratio increases to $18: 1$ and total new carbon $(\mathrm{TOC}=\mathrm{POC}+$ DOC) increases to 3 times that based on the Redfield ratio (Fig. 12B). We suspect that this 'excess' carbon is composed primarily of complex heteropolysaccharides, similar to what others have found in carbohydrateproducing diatoms (Myklestad et al. 1972, Frew et al. 1990). Both $S$. palmeriana and Pseudoquinardia recta are chain formers that produce loosely bound aggregates during growth which turn into highly condensed gelatinous masses after nutrient depletion (Goldman in press). Blooms of gelatinous-type species and subsequent aggregation are common occurrences in marine waters (Billett et al. 1983, Smetacek 1985, Alldredge \& Gotschalk 1989, Riemann 1989, Revelante \& Gilmartin 1991, Smith et al. 1991, Cushing 1992), frequently leading to the release of massive quantities of exudate (Ittekkot et al. 1981, Lancelot 1983). Wood \& Van Valen (1990) argue that exposure to high irradiance under conditions of nutrient depletion is a major factor controlling the release of early products of photosynthesis because the energy storing capacity of the cell is exceeded and photorespiratory pathways are not available. Other factors must be involved because exudate release occurred at low light in our study and there was no apparent effect of light intensity on excretion by the haptophyte Phaeocystis pouchetii in the study of Lancelot (1983) on North Sea phytoplankton dynamics.

The problem of exudate release by bloom-forming phytoplankton is tightly connected to the current controversy over the magnitude of DOC and DON concentrations in oceanic waters (Suzuki et al. 1985, Sugimura \& Suzuki 1988). One part of this controversy centers around the contention of Sugimura \& Suzuki (1988) that both DOC and DON concentrations in marine surface waters are considerably higher than previously measured and that the $\mathrm{C}: \mathrm{N}$ ratio of these organic fractions is about $6: 1$ to $7: 1$. Although there still is much uncertainty regarding the accuracy of the newer DOC numbers generated by high temperature combustion techniques (similar to the method we used in the present study), it has been far more difficult to replicate the higher DON numbers originally presented by Suzuki et al. (1985) (Walsh 1989, Maita \& Yanada 1990, Koike \& Lupas in press, Hansell et al. in press). In fact, it is difficult to conceptualize just where the DON would originate from to give such low $\mathrm{C}: \mathrm{N}$ ratios. As seen in our study and in many other laboratory and field studies, non nitrogenous compounds (chiefly carbohydrates) are the major exudates of phytoplankton.

A major unanswered question centers around the fate of these exudates. As diagrammed in Fig. 12B, some fraction of DOC must fuel bacterial growth within the microbial loop. Kirchman et al. (1991) found high turnover rates of DOC during a spring phytoplankton bloom in the North Atlantic, suggesting that at least some fraction of the exudate was highly labile. The sources of nitrogen to support both bacterial and phototrophic activity within the microbial loop clearly would be derived from regenerative processes during grazing resulting in $\mathrm{NH}_{4}{ }^{+}$excretion and recycling (Fig. 12B). In contrast, some other fraction of this DOC must be resistant to bacterial degradation, since it is known that phytoplankton exudates often are precursors of humictype materials which are known to be refractory (Rashid 1985, Gillam \& Wilson 1985). Earlier studies showing bacterial resistance to oxidation of deep ocean DOC (Barber 1968) support this latter view.

\section{Fate of large diatoms}

What is clear from our previous (Goldman in press) and current work is that there is no physiological barrier to large diatoms making a sizeable contribution to new production. The fact that some of the fast growing species such as Stephanopyxis palmeriana and Pseudoquinardia recta can aggregate in to large masses probably increases their sinking speeds tremendously. Thus direct export by sinking with minimal food chain losses most likely is an important process that follows new production (Cushing 1992). Another intriguing possibility, based on the concepts advanced by Longhurst and co-workers (Longhurst \& Harrison 1988, Longhurst et al. 1990), is that vertically migrating nekton and zooplankton graze large diatom populations at night in the euphotic zone and then migrate hundreds of meters to respire and excrete products at depth during the day. Such a rapid transport system would result in short and relatively efficient food chains with minimal losses (i.e. high new production). Some myc- 
tophid fish such as Ceratoscopelus warmingii, in fact, are known to graze on mats of Rhizosolenia spp., which are similar in form to aggregates produced by the chain-forming species in this study (Robison 1984). Whether or not this form of grazing is important in the ocean remains to be determined.

Acknowledgements. This study was supported by grant No. OCE-8818619 from the National Science Foundation.

\section{LITERATURE CITED}

Alldredge, A. L., Gotschalk, C. C. (1989). Direct observations of the mass flocculation of diatom blooms: characteristics, settling velocities and formation of diatom aggregates. Deep Sea Res. 36: 159-171

Banse, K. (1982). Cell volumes, maximal growth rates of unicellular algae and ciliates, and the role of ciliates in the marine pelagial. Limnol. Oceanogr. 27: 1059-1071

Barber, R. T. (1968). Dissolved organic carbon from deep waters resists microbial oxidation. Nature 220: 274-275

Belyayeva, T. V (1972). Distribution of large diatoms in the Southeastern Pacific. Oceanology 12: 400-407

Billett, D. S. M., Lampitt, R. S., Rice, A. L., Mantoura, R. F. C. (1983). Seasonal sedimentation of phytoplankton to the deep-sea benthos. Nature 302: 520-522

Blasco, D, Packard, T. T., Garfield, P. C. (1982). Size dependence of growth rate, respiratory electron system activity, and chemical composition of marine diatoms in the laboratory. J. Phycol. 18: 58-63

Brzezinski, M. A. (1985). The Si:C:N ratio of marine diatoms: Interspecific variability and the effect of some environmental variables. J. Phycol. 21: 347-357

Clemons, M. J., Miller, C. B. (1984). Blooms of large diatoms in the oceanic subarctic Pacific. Deep Sea Res. 31. 85-95

Cushing, D. H. (1992). The loss of diatoms in the spring bloom. Phil. Trans. R. Soc. Lond. (Ser. B) 335: 237-246

Drebes, G. (1966). On the life history of the marine plankton diatom Stephanopyxis palmeriana. Helgoländer wiss. Meeresunters. 13: 101-114

Dugdale, R. C., Goering, J. J. (1967). Uptake of new and regenerated forms of nitrogen in primary production. Limnol. Oceanogr. 12: 196-206

Eppley, R.W. (1972). Temperature and phytoplankton growth in the sea. Fish. Bull. U.S. 70: 1063-1085

Eppley, R. W., Peterson, B. J. (1979). Particulate organic matter flux and planktonic new production in the deep ocean. Nature 282: 677-680

Eppley, R. W., Sloan, P. R. (1966). Growth rates of marine phytoplankton: Correlation with light absorption by cell chlorophyll a. Physiol. Plant. 19: 47-59

Fenchel, T. (1982). Ecology of heterotrophic microflagellates. II. Bioenergetics and growth. Mar. Ecol. Prog. Ser. 8: 225-231

Frew, N. M., Goldman, J. C., Dennett, M. R., Johnson, A. S (1990). Impact of phytoplankton-generated surfactants on air-sea gas exchange. J. geophys. Res. 95: 3337-3352

Gavis, J. (1976). Munk and Riley revisited: nutrient diffusion transport and rates of phytoplankton growth. J. mar. Res. 34: $161-179$

Gillam, A. H., Wilson, M. A. (1985). Pyrolysis-GC-MS and NMR studies of dissolved seawater humic substances and isolates of a marine diatom. Org. Geochem. 8: 15-25

Goldman, J. C. (1986). On phytoplankton growth rates and particulate C:N:P ratios at low light. Limnol. Oceanogr. 31: 1356-1361

Goldman, J. C. (1988). Spatial and temporal discontinuities of biological processes in pelagic surface waters. In: Rothchild, B. J. (ed.) Towards a theory on biological and physical processes in the world ocean. Kluwer Academic, Dordrecht, p. 273-296

Goldman, J. C. (in press). Potential role of large diatoms in new primary production. Deep Sea Res.

Goldman, J. C., McCarthy, J. J., Peavey, D. G. (1979). Growth rate influence on the chemical composition of phytoplankton in oceanic waters. Nature 279: 210-215

Guillard, R. R. L., Kilham, P. (1977). The ecology of marine planktonic diatoms. In: Werner, D. (ed.) The biology of diatoms. Univ. Calif. Press, Berkeley, p. 372-469

Hansell, D. A. (in press). Results and observations from the measurement of DOC and DON in seawater using a high temperature catalytic oxidation technique. Mar. Chem.

Hansell, D. A., P. M. Williams, B. B. Ward (in press). Measurements of DOC and DON in the Southern California Bight using oxidation by high temperature combustion. Deep Sea Res.

Ittekkot, V., Brockmann, U., Michaelis, W., and Degens, E. T. (1981). Dissolved free and combined carbohydrates during a phytoplankton bloom in the northern North Sea. Mar. Ecol. Prog. Ser. 4: 299-305

Jenkins, W. J., Goldman, J. C. (1985). Seasonal oxygen cycling and primary production in the Sargasso Sea. J. mar. Res. 43: $465-491$

Kirchman, D. L., Suzuki, Y., Garside, C., Ducklow, H. W. (1991). High turnover rates of dissolved organic carbon during a spring phytoplankton bloom. Nature 352 : 612-614

Koike, I, Lupas, L. (in press). Dissolved organic nitrogen in the northern North Pacific assessed by a high temperature combustion method. Mar. Chem.

Lancelot, C. (1983). Factors affecting phytoplankton extracellular release in the Southern Bight of the North Sea. Mar Ecol. Prog. Ser. 12: 115-121

Legendre, L., Gosselin, M. (1989). New production and export of organic matter to the deep ocean: consequences of some discoveries. Limnol. Oceanogr. 34: 1374-1380

Longhurst, A. R., Harrison, W. G. (1988). Vertical nitrogen flux from the oceanic photic zone by diel migrant zooplankton and nekton. Deep Sea Res. 35: 881-889

Longhurst, A. R., Bedo, A. W., Harrison, W. G., Head, E. J. H., Sameoto, D. D. (1990). Vertical flux of respiratory carbon by oceanic diel migrant biota. Deep Sea Res. 37: 685-694

Maita, Y., Yanada, M. (1990). Vertical distribution of total dissolved nitrogen and dissolved organic nitrogen in seawater. Geochem. J. 24: 245-254

Martin, J. H., Fitzwater, S. E. (1988). Iron deficiency limits phytoplankton growth in the north-east Pacific subarctic. Nature 331. 341-343

McCarthy, J. J., Kamykowski, D. (1972). Urea and other nitrogenous nutrients in La Jolla Bay during February, March, April, 1970. Fish. Bull. U.S. 70: 1261-1274

Morel, F. M. M., Rueter, J. G., Price, N. M. (1991). Iron nutrition of phytoplankton and its possible importance in the ecology of ocean regions with high nutrients and low biomass. Oceanography 4: 56-61

Mullin, M. M., Sloan, P. R., Eppley, R. W. (1966). Relationship between carbon content, cell volume and area in phytoplankton. Limnol. Oceanogr. 11: 307-311

Murphy, J., Riley, J. P. (1962). Determination of phosphate in natural waters. Analytica chim. Acta $27: 31-36$

Myklestad, S. (1974). Production of carbohydrates by marine 
planktonic diatoms. I. Comparison of nine different species in culture. J. exp. mar. Biol. Ecol. 15: 261-274

Myklestad, S., Hang, A., Larson, B. (1972). Production of carbohydrates by the marine diatom Chaetoceros affinis var Willei (Gram) Hustedt. II. Preliminary investigation of the extracellular polysaccharides. J. exp. mar. Biol. Ecol. 9: $137-144$

Paasche, E (1980). Silicon content of five marine plankton diatom species measured with a rapid filter method. Limnol. Oceanogr. 25: 474-480

Parsons, T. R., Maita, Y., Lalli, C. M. (1984). A manual of chemical and biochemical methods for seawater analysis. Pergamon Press, New York

Pasciak, W. J., Gavis, J. (1975). Transport limited nutrient uptake rates in Ditylum brightwellii. Limnol. Oceanogr. 19: 881-888

Rashid, M. A. (1985). Geochemistry of marine humic compounds. Springer-Verlag, New York

Revelante, N., Gilmartin, M. (1991). The phytoplankton composition and population enrichment in gelatinous 'macroaggregates' in the nothern Adriatic during the summer of 1989. J. exp. mar. Biol. Ecol. 146: 217-233

Riemann, F. (1989). Gelatinous phytoplankton detritus aggregates on the Atlantic deep-sea bed. Structure and mode of formation. Mar. Biol. 100: 533-539

Robison, B. H. (1984). Herbivory by the myctophid fish Ceratoscopelus warmingii. Mar. Biol. 84: 119-123

Schöne, H. K. (1982). The influence of light and temperature on the growth rates of six phytoplankton species from the upwelling area off Northwest Africa. Rapp. P.-v. Réun. Cons. int. Explor. Mer. 180: 246-253

Schöne, H. K., Schöne, A. (1982). MET 44: a weakly enriched sea-water medium for ecological studies on marine plankton algae, and some examples of its application. Botanica Mar. 25: 117-122

Smetacek, V S. (1985). Role of sinking in diatom life-history cycles: ecological, evolutionary and geological significance. Mar Biol. 84: 239-251

Smith, W. O., Codispoti, L. A., Nelson, D. M., Manley, T.,

This article was submitted to the editor
Buskey, E. J., Niebauer, H. J., Cota, G. F. (1991). Importance of Phaeocystis blooms in the high-latitude ocean carbon cycle. Nature 352: 514-516

Solorzano, L., Sharp, J. H. (1980). Determination of total dissolved phosphorus and particulate in natural waters. Limnol. Oceanogr 25: 754-758

Sommer, U. (1986). Nitrate- and silicate-competition among antarctic phytoplankton. Mar Biol. 91: 345-351

Sommer, U. (1989). Maximal growth rates of Antarctic phytoplankton: Only weak dependence on cell size. Limnol. Oceanogr. 34: 1109-1112

Sournia, A. (1982). Form and function in marine phytoplankton. Biol. Rev. 57 347-394

Strickland, J. D. H., Parsons, T. R. (1972). A practical handbook of seawater analysis, 2nd edn. Bull. Fish. Res. Bd Can. 167: 1-310

Sugimura, Y., Suzuki, Y (1988). A high temperature catalytic method of non-volatile dissolved organic carbon in seawater by direct injection of liquid sample. Mar. Chem. 24: 105-131

Suzuki, Y. Sugimura, Y., Itoh, T. (1985). A catalytic oxidation method for the dermination of total nitrogen dissolved in seawater. Mar. Chem. 16: 83-97

Tett, P. S., Heaney, S. I., Droop, M. R. (1985). The Redfield ratio and phytoplankton growth rate. J. mar. biol. Ass. U.K. 65: 487-504

Walsh, T. W. (1989). Total dissolved nitrogen in seawater: a new high-temperature combustion method and a comparison with photo-oxidation. Mar. Chem. 26: 295-311

Waterbury, J. B., Watson, S. W., Valois, F. W., Franks, D. G. (1986). Biological and ecological characterization of the marine unicellular cyanobacterium Synechococcus. In: Platt, T., Li, W. K. W. (eds.) Photosynthetic picoplankton. Bull. Fish. Aquat. Sci. 214: 71-120

Wood, A. M., van Valen, L. M. (1990). Paradox lost? On the release of energy-rich compounds by phytoplankton. Mar Microb. Food Webs 4: 103-116

Wood, E. D., Armstrong, F. A. J., Richards, F. A. (1967). Determination of nitrate in seawater by cadmium-copper reduction to nitrite. J. mar biol. Ass. U.K. 47: 23-31

Manuscript first received: June 2, 1992

Revised version accepted: October 2, 1992 